receptors ; but if red light is used, there is a slight change of fixation to bring a cluster of 'red' receptors into action. Several experiments were made showing that slight changes in the direction of fixation for lights of different colours do occur. These changes in fixation, together with the changes observed in the apparent colour of very small test stimuli, are also regarded by Prof. Hartridge as strong evidence for the existence in the human retina of some seven types of receptor with narrow spectral sensitivity curves analogous to the modulator curves obtained in Granit's electrophysiological studies on animals (polychromatic theory of human vision).

One difficulty with this paper is that Prof. Hartridge has not only lost faith in the trichromatic theory, but he has also, it seems, abandoned the whole mode of approach through colour-matching measurements by which the purely empirical structure of the theory has been built up. One feels that the new ideas, if valid, must interlock with this empirical structure; but Prof. Hartridge does not show that they do.

W. S. Stiles

\section{FRUIT AND VEGETABLE CULTURE}

THE annual report for 1945 of the Agricultural and Horticultural Research Station at Long Ashton, Bristol, gives results of the Station's work on the scientific horticulture of fruit and vegetable crops and on their products.

Classification of the visual symptoms of mineral deficiencies of crop plants is continued by E. J. Hewitt. He uses various refinements in technique, including a 'Permutit' demineralization method of purifying rain-water for studies of iron deficiency, and a method for transplanting adult plants without root disturbance. The present survey embraces deficiencies of twenty-nine crops grown in sand culture, and one incidental result is that a high nitrogen-level accentuates the symptom expressive of boron deficiency. Some of the effects of soil acidity on crops are not yet fully understood, and Hewitt also has a progress report on this matter. It would seem that some at least of the symptoms of acid damage are those of manganese toxicity, and other interesting tentative conclusions are mentioned. D. J. D. Nicholas has investigated the validity of rapid chemical tests for the diagnosis of mineral deficiencies in potato plants. He finds a welcome accord with the results of the full chemical analysis, and with the visual symptoms. Several useful correlations between deficiencies and toxicities are established. Spraying the foliage of tomato crops with 2 per cent magnesium sulphate solution is found to be a much better control of magnesium deficiency than soil applications of the same substance, according to D. J. D. Nicholas, J. O. Jones and T. Wallace. The director of the Station, Prof. T. Wallace, with E. Catlow, gives two extensive reports on the manuring of potatoes and garden beet respectively.

A useful classification of power-operated hydraulic spraying machinery for fruit crops has been prepared by $H$. G. H. Kearns. He gives broad specifications for the chief components of spray outfits, and estimates the biological requirements of spraying. Growers should find this paper a useful practical guide to the choice of this section of equipment. The advent of D.D.T. and benzene hexachloride makes it necessary to find the best methods of incorporating these sprays in a comprehensive programme. H. G. H.
Kearns, R. W. Marsh and H. Martin have made experiments on this problem, which rather suggest that D.D.T. is an excellent insecticide against certain pests, but offers no widespread panacea of control. It was effective against leaf-curling aphids. Comparisons of three fungicides-tetramethylthiuram, ferric dimethyldithio-carbamate, and copper sebacate -were also included. The last-mentioned was approximately equal to lime sulphur as a fungicide. Other papers in this section deal with the flight period of the codling moth in relation to time of spraying $(\mathrm{S} . \mathrm{H}$. Bennett), the effect of early lifting and other factors on storage losses of onions (H. E. Croxall), attack of lettuce by two strains of the fungus Bremia lactuca, and the relation of the disease to wild species of Lactuca (L. Ogilvie), and clover-rot investigations by Moira Munro and L. Ogilvie. The general features of eelworm attacks of vegetable crops are reviewed by $\mathbf{H}$. W. Miles and Mary Miles, and A. J. Lloyd briefly outlines results of a biological method of estimating the intensity of clover stem eelworm infections in field soils. A short paper by May $J$. Haddock shows that the 'turnip flea beetle' is not a single species, but a complex of as many as eight species. They all seem to have a wide taste for cruciferous plants; but this numerical expansion of species does not seem to offer any change in methods of control.

The Station has also investigated problems relating to fruit and vegetable products. Workers in this field will find papers on the control of blackening of boiled potatoes, factors affecting quality in potatoes and tomatoes, the apple as a source of vitamin $\mathrm{C}$, and the Station's major cider research.

\section{APPOINTMENTS VACANT}

APPLICATIONS are invited for the following appointments on or before the dates mentioned :

LABORATORY ASSISTANT (Grade II) IN THE DEPARTMRNT OF ChEMISTRY-The Secretary, Bedford College for Women, Regent's Park, London, N.W.1 (December 29).

VRTERINARY INSPECTORS in the Ministry of Agriculture for Northern Ireland-The Secretary, Civil Service Commission, Stormont, Belfast (December 31).

AssistanT ChamsT in the Chiswick Laboratory-The Staff Officer (ER/E. 457), London Passenger Transport Board, 55 Broadway, Condon, S.W.1 (December 31).

SENIOR LECYURER, and a READER, IN AGRICULTURE, at Makerere College, East Africa-The Secretary, Inter-University Council for Higher Qucation in the Colonies, 8 Park Street, London, W.1 (December 31). QUALIFTED CHEMTSTS in the Generating Stations at Chelsea and Neasden-The Staff Officer (ER/E. 454), London Passenger Transport Board, 55 Broadway, London, S.W.1 (December 31).
BACTERIOLOGIST to take charge of a public health laboratory service in Belfast-The Establishment officer, Ministry of Health and Local Government, Stormont, Belfast (December 31). RASEARCH FELLOW to work on the problem of origin and measurement of stresses in cast metal product -The Professor of Industrial Metallurgy, The University, Edgbaston, Birmingham 15 (December 31). Demonstrator (part-time) IN THE PhaRMacologr DEPARTMGNT
The Dean, Guy's Hospital Medical School, London, S.E.1 (December 31).

31. Letroker IN ANatomy at Makerere College, East Africa-The Secretary, Inter-University Council for Higher Education in the Colonies, 8 Park Street, London, W.1 (January 1).

Colonies, 8 Park Street, London, W.1 (January 1). The Secretary, The University, Edmund Street, Birmingham (January I).

Lecturar (Grade IIc) IN Pharmagotogy--The Secretary, The University, Edmund Street, Birmingham 3 (Tanuary 8 ).

SCIENTIFIO OFFICER IN THE BLOOD TRANSFUSION LABORATORIES, Manchester-The Regional Transfusion Officer, Royal Infirmary, anchester 13 (January 10)

LEOTURER (Grade IIc) IN EIECTRICAL ENGINHERINQ-The Secretary, The University, Edmund Street, Birmingham 3 (January 10).

SGNIOR SOIENTIFIO OFFIOER OI SCIENTIFIC OFFICER (Ref. No. A.337/47), and a SFNIOR EXPERIMENTAL OFHICER Or EXPRRIMENTA OFFIOER (Ref. No. F.773/47), at the Atomic Energy Research Estab ishment, Harwell, Dldcot, Berks-The Ministry of Labour and National Service, Technical and Scientific Register, Room 669, York House, Kingsway, London, W.C.2, quoting appropriate Ref. No. (January 10).

DIRECTOR of a new Vegetable Research Station-The Chairman. Organising Committee, Vegetable Research Station, Ministry of Agriculture, Block 4, Bickenhall Mansions, Baker Street, London, W.1 (January 24). 